
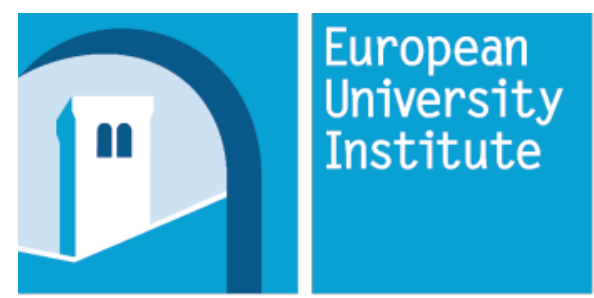

\title{
MAX WEBER
}

PROGRAMME FOR

POSTDOCTORAL

STUDIES

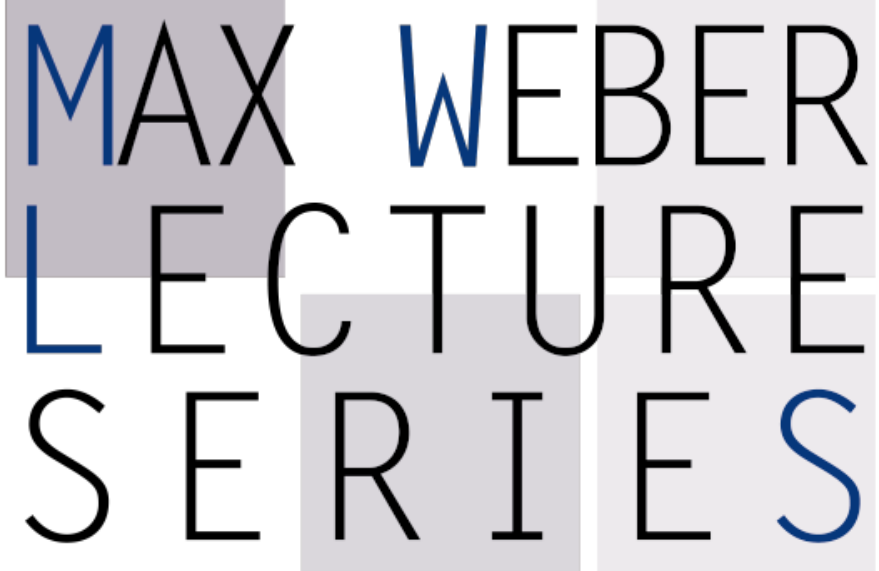

MWP - 2016/05

Max Weber Programme

Religious Dimensions of Political Conflict and Violence

Rogers Brubaker 

European University Institute Max Weber Programme

Religious Dimensions of Political Conflict and Violence

Rogers Brubaker

Max Weber Lecture No. 2016/05 
This text may be downloaded for personal research purposes only. Any additional reproduction for other purposes, whether in hard copy or electronically, requires the consent of the author(s), editor(s). If cited or quoted, reference should be made to the full name of the author(s), editor(s), the title, the working paper or other series, the year, and the publisher.

ISSN 1830-7736

(C) Rogers Brubaker, 2016

Printed in Italy

European University Institute

Badia Fiesolana

I - 50014 San Domenico di Fiesole (FI)

Italy

www.eui.eu

cadmus.eui.eu 


\begin{abstract}
How should we understand the religious dimensions of political conflict and political violence? One view sees religiously grounded conflict and violence as sui generis, with a distinctive logic or causal texture. The alternative view subsumes them under political conflict and violence in general, or under the rubric of politicized ethnicity. I seek to highlight both the distinctiveness of religiously informed political conflict and the ways in which many conflicts involving religiously identified claimants are fundamentally similar in structure and dynamics to conflicts involving other culturally or ethnically defined claimants. I identify the distinctively religious stakes of certain political conflicts, informed by distinctively religious understandings of right order. And I specify six violence-enabling modalities and mechanisms (though all can also enable nonviolent solidaristic or humanitarian social action): (1) the social production of hyper-committed selves; (2) the cognitive and affective construction of extreme otherhood and urgent threat; (3) the mobilization of rewards, sanctions, justifications, and obligations; (4) the experience of profanation; (5) the translocal expandability of conflict; and (6) the incentives generated by decentralized and hyper-competitive religious fields. None of these violence-enabling modalities and mechanisms is uniquely religious; yet religious beliefs, practices, structures, and processes provide an important and distinctively rich matrix of such modalities and mechanisms.
\end{abstract}

\title{
Keywords
}

Religiously informed political conflict, religious stakes in political conflict, violence-enabling modalities and mechanisms.

The lecture was delivered on 15 June 2016. The talk draws freely on Brubaker 2015b.

Rogers Brubaker

University of California (UCLA) 

I'm deeply honored to have been asked to deliver one of your Max Weber lectures. I became a sociologist by struggling to come to terms with Weber's work, which remains as rich, difficult, and compelling today as it was a century ago. One of the very first things I was assigned to read as a college student was the dense and difficult section on the "Types of legitimate domination" from Part One of Economy and Society, rendered more difficult still by the fact that we were using the less than felicitous translation of A. M. Henderson and Talcott Parsons. I found the section impenetrable yet somehow also compelling; I underlined every word; and I was hooked. I ended up writing my undergraduate senior thesis, which eventually became my first book, on the idea of rationality in Weber's work; and though I never took a sociology class in college, I decided to attend graduate school in sociology.

Religion, conflict, and violence: few themes, taken separately, were more central to Weber's work than these. The themes come together at certain points in his work. Conflict and struggle were central to Weber's sociology of religion, as they were to all his work; and Weber's compendium on the sociology of religion in Economy and Society touched briefly on the development across religious traditions of the notion of holy war. Violence was of course for Weber the "specific means" of politics; and in "Politics as a Vocation," Weber memorably wrote that "whoever "contracts with violent means for whatever ends - and every politician does - is exposed to its specific consequences. This holds especially," Weber continued, "for the Crusader, religious and revolutionary alike" (1946: 124-25). In another famous passage from that lecture, Weber explored the "ethical paradoxes" (125) arising from the experience of what he called the "ethical irrationality of the world"; he commented on the tendency for a believer in an ethic of ultimate ends - religious or secular - to turn into a chiliastic prophet, willing to employ violence "one last time" in order to bring about a world without violence (122). More generally, Weber's theory of charisma as the "specifically revolutionary force" in history also brought together religion, politics, and violence.

But the question of the religious dimensions of political conflict and violence is of course posed in different terms for us today. Indeed the question is hard to escape these days. Political scientists - who were long strikingly uninterested in religious phenomena - have "found religion" with a vengeance in the last decade or so, while sociologists, anthropologists, and historians of religion, as well as others in the field of religious studies, have become increasingly interested in political conflict and violence. The reasons for this dual development are obvious : in general terms, the resurgence of "public religion" - politically active and contentious forms of religious engagement - in a range of settings in which religion had been prevailingly understood as a private matter; and, more specifically, the shock of the Iranian revolution, the rise of politically active fundamentalist movements in all major religious traditions, and the prominent implication of religion in a spate of civil wars and terrorist campaigns. The question of the religious dimensions of political conflict and violence continues to insist itself into relevance, brought into focus by the headlines with depressing regularity, including of course the headlines from Orlando on Sunday.

So how should we understand the religious dimensions of political conflict and political violence? There are two broad ways of thinking about this. One view - I'll call this the particularizing view - sees religiously grounded conflict and violence as sui generis, with a distinctive logic or causal texture. This view takes religious claims seriously - perhaps too seriously. The alternative, generalizing view is that what appears to be religiously inspired conflict and violence are best subsumed under political conflict and violence in general, or under the abstract rubric of politicized ethnicity. On this view, religious claims may mask other, more important causal factors; religion is at best incidental to the logic or causal texture of the conflict or violence.

In my view, these stances need not be mutually exclusive. We can bring into analytical focus both the distinctiveness of religiously informed political conflict and the ways in which many conflicts involving religiously identified claimants are fundamentally similar in structure and dynamics to conflicts involving other culturally or ethnically defined claimants. 
I'll begin with the generalizing stance. But I'll devote most of my lecture to specifying some distinctive ways in which religion is implicated in political conflict and violence. I do so not because I think the particularizing approach is superior, but because it is less well developed. The generalizing stance is clear and well defined; the particularizing stance is not. And the strongest and clearest particularizing statements - those that propose the strongest forms of religious exceptionalism - are simply untenable. ${ }^{1}$ The challenge is to develop a more nuanced account of the distinctive ways in which religion can enter into political conflict and violence.

A potential objection to this analytical strategy is that "religion" and "religious" are hopelessly inadequate as analytical categories. They are better understood as essentially contested categories of practice. On this understanding, "religion" per se does not exist. What exists - and what may sustain, enable, or justify political violence in certain contexts - are particular practices, discourses, and structures that are understood by practitioners as "religious," though in some cases their religious legitimacy may be vehemently denied by others claiming religious authority.

I am sympathetic to this position. A fuller and more rigorous treatment would have to forego the use of "religion" or "religious" as categories of analysis, or at least be much more self-reflexive about defining and using these categories. Yet given the exploratory nature of this discussion, I am willing to work here with a relatively casual and imprecise notion of "religion," as long as we keep in mind that this designates not a unitary "thing" but a loosely related set of practices, discourses, and structures for which religious sanction is claimed.

\section{The generalizing stance: religion as a form of ethnicity}

So let me begin with the generalizing stance that treats religion as simply one of a number of functionally equivalent bases of identity and mobilization. This stance developed in the context of the study of ethnicity. Two strands of work can be distinguished. The first goes back to the late Fredrik Barth's influential Introduction to Ethnic Groups and Boundaries a half century ago, Barth called for redirecting attention from observable patterns of shared culture to the categorical distinctions that organize and channel social interaction. The nature and dynamics of such boundaries could be studied without regard to what Barth rather dismissively - and to his later regret ${ }^{2}$ - referred to as the "cultural stuff," that is, patterns of cultural similarity and difference. In Barth's words, "The critical focus of investigation... becomes the ethnic boundary that defines the group, not the cultural stuff that it encloses".

The second strand of work emerged from efforts in the 1970s and 1980s to make sense of the surge of political mobilization on the basis of putatively "primordial" identities - language, race, religion, caste, tribe, or indigeneity. ${ }^{3}$ Ethnicity was constituted as an object of study in this line of work by abstracting from the specificities of language, religion, and other ascriptive markers such as phenotype, region of origin, and customary mode of livelihood, and by reducing these to their common denominator as markers of identity and difference and bases of solidarity.

Joseph Rothschild was one of the most sophisticated proponents of this line of work. (He was also, of course, one of the most sophisticated analysts of East central European society and politics.) According to Rothschild, it would be pointless to "separate out the notion of ethnic consciousness, solidarity, and assertiveness from religious, linguistic, racial, and other so-called primordial foci of consciousness, solidarity, and assertiveness." If this were to be done, he continued, "it is difficult to

\footnotetext{
${ }^{1}$ See Gorski and Türkmen-Dervişoğlu's (2013: 196-7) cogent critique of sweeping arguments about the connection between monotheism and violence and still more sweeping arguments about the intrinsic connections between religion per se and violence.

${ }^{2}$ Looking back on his 1969 piece a quarter century later, Barth suggested that "the issue of cultural content versus boundary, as it was formulated, unintentionally served to mislead" (1994:17).

${ }^{3}$ Many variants of modernization theory, it should be noted, were considerably more sophisticated than their critics allowed. Far from being baffled by politicized ethnicity, sophisticated modernization theorists such as Karl Deutsch, Ernest Gellner, and especially the young Clifford Geertz developed powerful if incomplete explanations of it. For a brief reappraisal, see Brubaker 2015a, Chapter 7.
} 
see what precisely would be... meant by the residual notion of ethnicity and ethnic groups." (Rothschild 1981:9). Whether political entrepreneurs mobilize along the lines of religion or language or race, Rothschild went on, "is intrinsically irrelevant, since any and every one of them can be sacralized into a symbolic focus of ethnic mobilization and politicization, and this process is more or less the same whichever marker-criterion is selected" (ibid.: 98 emphasis added).

The Barthian study of ethnic boundaries and the political science study of politicized ethnicity developed independently of one another, though they have subsequently converged. Barth and his immediate followers were concerned with social organization, while the political scientists were concerned with political mobilization and claims-making. But both lines of work treated ethnicity as a culturally "empty" form. Both lines of work discounted culture: what mattered was not how difference and identity were culturally construed, but how they were socially organized and politically expressed.

One might trace the generalizing strategy back still further to Max Weber's fragmentary but powerful observations on social closure. For Weber, the recurrent process of closure, involving the monopolization of material and ideal opportunities, is independent of the substantive cultural content of insider or outsider groupings. As Weber put it, "some externally identifiable characteristic of a subset of the (actual or potential) competitors - race, language, religion, geographic or social origin, descent, place of residence, etc. - is taken by the others as the occasion for seeking to exclude them from competing. What characteristic this is in individual cases is irrelevant: whatever most readily presents itself is utilized." ${ }^{4}$

There is a certain irony here: Weber's monumental analyses of religion were particularizing, not generalizing; they took seriously both the distinctive content of religious ideas and the distinctive forms of religious organization. Yet Weber's notion of social closure as a culturally empty social form had much in common with Barth's emphasis on boundaries rather than cultural content; and Weber's writings on closure also served as an inspiration for more recent generalizing treatments of politicized ethnicity such as that of Andreas Wimmer (2013), as well as for Charles Tilly's (1998) generalizing theory of categorical inequality.

Be that as it may, work in this generalizing tradition subsumes religion - along with race, caste, kinship, region, language, indigeneity, and nationality - under the abstract, culturally empty rubric of ethnicity.

Religion never comes into analytical focus in this tradition. This work does not start with politicized religion, and then make a case for subsuming it under a broader conceptual or theoretical rubric. Rather, it starts with ethnicity, which it defines broadly enough to embrace religion. Religion is never at the center of analytical attention.

In the remainder of my lecture, I will start from politicized religion rather than from politicized ethnicity; and I will consider some possibly distinctive ways in which religion can inform and inflect political conflict. I consider first how religion can define the stakes of conflict, and second how it can shape the modalities and mechanisms of conflict.

\section{Stakes: the substantive regulation of public life}

So let me start with the stakes of conflict. Conflicts involving religiously identified parties or claimants need not involve religiously defined stakes. They may be conflicts over political power, economic resources, symbolic recognition, cultural reproduction, or national self-determination. This is what makes it possible and fruitful to subsume religion, for certain purposes, under the rubric of politicized ethnicity. In Northern Ireland, for example, the parties to the conflict are often identified as "Catholics" and "Protestants." But the stakes of the conflict are not religious. The same holds for the conflict between "Muslims," Orthodox Serbs, and Catholic Croats in the former Yugoslavia. To a considerable extent, this holds also for the contemporary conflicts between "Shiites" and "Sunnis" in Iraq and elsewhere, or between "Alawites" and "Sunnis" in Syria, though these contemporary cases involve both ethnopolitical conflicts over "who owns the state" - as my former colleagues Andreas

\footnotetext{
${ }^{4}$ Weber 1964 [1922] 260; cf. Weber 1978: 342. (As the translation is misleading, I have provided my own.)
} 
Wimmer (1997) put it - and conflicts with distinctively religious stakes, pitting some religiously militant Sunnis against other Sunnis as well as against Shiites and Alawites.

Yet in other contexts, one can't assimilate religious to ethnopolitical conflict. Here it is important to distinguish the boundary-defining or group-constituting aspect of religion from the normative ordering power intrinsic to many forms of religious life. The boundary-defining aspect allows religion to be treated, for certain purposes, as a form of (politicized) ethnicity. But the normative ordering power of religion points to the distinctively religious stakes of certain political conflicts.

Let me say a word about this normative ordering power and how it can generate distinctively religious stakes of political conflicts. Religious understandings of right order exist at personal, familial, communal, societal, and cosmic levels. In many traditions of serious or demanding religiosity, ${ }^{5}$ forms of right order (or disorder) at these various levels are understood to be closely interconnected. Common to "fundamentalisms" in many religious traditions, for example, is the argument that disorder in the family (which may be attributed to feminism, unregulated sexuality, divorce, or lack of respect for paternal or husbandly authority) contributes to disorder in wider communal, societal, and political spheres (Friedland 2002; Hawley 1994). This explains the priority accorded in these traditions to restoring right order in the sphere of family and sexuality.

Political claims arising from distinctively religious understandings of right order cannot be subsumed under a paradigm of politicized ethnicity. This is not because of the intensity of the conflict; ethnic and nationalist conflicts can be just as intense. It's because conflict turns on the question of how we should live, not just on questions of the questions of recognition, resources, and opportunities for cultural reproduction that are central to politicized ethnicity. Ethnic identities may be as deeply felt as religious identities; but they are normatively thin, with few implications for the substantive regulation of public life.

Today, the most salient religiously driven political conflicts over the substantive regulation of public life turn on claims for the implementation of shari'a, which have been central to political contestation throughout much of the Muslim world since the 1970s. What Robert Hefner has called "Shari'a politics" - that is, struggles over the "place and authority of the shari'a in society" - assume widely varying forms, as do understandings of what shari'a means in contemporary contexts. But the regulation of gender, sexuality, and family is almost always at stake in such conflicts, as are questions of religious freedom and relations between Muslims and non-Muslims (Hefner 2011: 22).

Outside the Muslim world, religiously driven political conflicts likewise pivot on the regulation of gender, sexuality, and the family (Friedland 2002). Conflicts over the substantive regulation of public life in the United States, for example, arise from the Christian right's efforts to ban abortion, prohibit gay marriage, restrict access to contraception, restore school prayer, and require the teaching of creationism or intelligent design in school. Similar conflicts arise from ultra-orthodox Jewish claims in Israel that public buses not operate on Saturdays; that sex segregation be observed in public spaces in their neighborhoods; that sex-segregated bus lines serve their communities; and that sex segregation be preserved at the Western Wall.

Religion is of course not the only source of claims about the right ordering of public life. The exhaustion of communism and fascism has reduced the salience of conflict driven by comprehensive secular ideological commitments, but moral crusades, social movements, and other forms of political contestation continue to be driven by secular as well as religiously informed moral commitments and understandings of right order (Jasper 1997). Still, religion is a distinctively comprehensive and durable source of politically relevant understandings of right order; and this potent normative ordering power is what distinguishes political conflict with distinctively religious stakes from ethnopolitical and ethnonational conflict between parties who are identified in religious terms.

\footnotetext{
${ }^{5}$ I don't mean here particular religions, but particular forms of all major religious traditions.
} 


\section{Modalities and mechanisms}

I've suggested that some forms of political conflict involve distinctively religious stakes. For the remainder of my lecture, I want to suggest some ways in which religiously informed political conflict and violence - and from here on I'll be focusing on violent conflict - can be sustained by a distinctive matrix of modalities and mechanisms.

I'll identify and comment briefly on six modalities and mechanisms. I'll itemize them now, just to give you a roadmap of where I'll be going. The first is the social production of hypercommitted selves. The second is the cognitive and affective construction of extreme otherhood and urgent threat. The third is the mobilization of specifically religious rewards, sanctions, justifications, and obligations. The fourth is the experience of profanation. The fifth is the translocal expandability of conflict. And the last is the incentives generated by decentralized and hyper-competitive religious fields. This enumeration is neither systematic nor exhaustive; it is exploratory and illustrative. Moreover, these are not specific mechanisms; each designates a broad class of modalities, mechanisms, and processes.

So let me begin with the first mechanism, which is what I call the social production of hypercommitted selves. By this I mean selves constituted by radical and uncompromising forms of commitment to a political, moral, or religious cause. The cause is understood as an unconditional and absolute value, not as one good among others. This stance is what Max Weber called a Gesinnungsethik, an "ethic of conviction" or "ethic of ultimate ends." The ethic of conviction is characterized by indifference to the consequences of action, as illustrated by the maxim "the Christian acts rightly and leaves the outcome to God" (Weber 1978b:82). ${ }^{6}$

Hyper-commitment need not entail violence; the cause to which one is committed may even expressly repudiate violence. But there is an affinity between hyper-commitment and intransigence and violence. The indifference to consequences can facilitate both the suffering and the inflicting of violence. It does so by suspending ordinary forms of moral accounting, and everyday sensitivity to risk and harm, in the name of an overriding concern with the one thing that matters. At the limit, this may entail indifference to the possibility or even certainty of one's own death, or indifference to the deaths of others. The discounting of consequences is the source of the extreme moral ambivalence of hypercommitment, which can enable both self-sacrificing forms of moral heroism and self-righteous forms of morally sanctified violence.

There is of course nothing uniquely religious about radical and uncompromising commitment to a cause. The paradigmatic ethic of conviction, for Weber, was religious; but in his great lecture "Politics as a Vocation," delivered in January 1919, during the turmoil of the November Revolution, Weber was more concerned with secular forms, and specifically with revolutionary syndicalism (1946:120-1). And all high-risk secular collective action requires commitment and the discounting of risks.

Still, religion's formidable socializing and world-defining powers make it a distinctively robust and productive source of hyper-committed selves. The power to shape selves and subjectivities and to define reality comes into focus most clearly in the case of conversion to a new and more demanding and integral form of religious engagement. ${ }^{7}$

Conversion can involve a fundamental shift in identity, a rupture in the way of seeing and experiencing the world, a relativization and devaluation of existing social ties, and a powerful cognitive, emotional, moral, and bodily re-socialization. Obviously certain secular organizations and movements also employ techniques of re-socialization in their efforts to produce highly committed

\footnotetext{
${ }^{6}$ In the analytical idiom of Economy and Society, this involves a purely wertrational or "value-rational" orientation of action on the basis of a "conscious belief in the unconditional, intrinsic value [Eigenwert] of some ethical, aesthetic, religious or other form of behavior as such, independently of its consequences", rather than the weighing of costs and benefits and likely consequences of alternative lines of action characteristic of zweckrational or instrumentally rational action.

${ }^{7}$ By "conversion" I do not mean conversion from one religious affiliation to another, but rather from one mode of religious engagement to another, more demanding one (Snow and Machalek 1984).
} 
members, and commitment can intensify and crystallize in the course of unfolding struggles. But religion is a particularly potent matrix of the profound and durable reorganization of the self. ${ }^{8}$

Conversion, of course, does not always produce a hyper-committed self. Religious commitment shades over into hyper-commitment only at the extreme endpoint of a continuum. But the logic of what Weber called "heroic" or "virtuoso" religiosity - premised on an implicitly comparative and competitive frame within which claims can be made for exceptional status on the basis of exceptional religious performance - makes hyper-commitment an immanent and everrecurring possibility. ${ }^{9}$ And when hyper-commitment is generated, it can contribute to uncompromising, high-risk, and sometimes violent forms of political action.

The second mechanism is the construction of extreme otherhood and urgent threat. The construction of otherhood is of course a general socio-cultural process, not a distinctively religious one. And while religion is implicated in the construction of otherhood, it is also involved in transcending divisions and constructing universalistic forms of solidarity (Stamatov 2013). Here again one sees what R. Scott Appleby (2000) calls the "ambivalence of the sacred."

Yet religion affords a distinctively potent, flexible, authoritative, renewable, transposable, and mutually reinforcing set of resources - at once symbolic, discursive, ritual, and organizational - for constructing extreme forms of otherhood that can facilitate and legitimize violence.

As authoritative systems of classification, many religious traditions contain specifically religious categories of extreme otherhood: heretic, apostate, infidel, and so on. ${ }^{10}$ They specify procedures (such as excommunication or, in the Muslim world, takfir) for placing persons in these categories. ${ }^{11}$ And they justify and authorize violence, in certain contexts, against members of these categories. Of course all religious traditions are internally contradictory, and justifications of violence stand in tension with other provisions. But categories of religiously legitimated extreme otherhood, and justifications for violence against such others, remain available as a potent discursive resource.

Religious traditions also contain elaborate and distinctive resources for constructing urgent threats and mobilizing and legitimizing action against them (Appleby 2000:82). Idioms of sacralization and profanation, of cosmological good and evil, of divinely sanctioned mission or holy war, and of imminent catastrophe or millenarian transformation can be enlisted to raise the stakes (Juergensmeyer 2000; Wessinger 2000). Judgments pronounced by religious authorities can enjoin action - including violent action - to respond to the threat.

More generally, religious understandings of transcendent reality offer powerful leverage for radically devaluing the existing social and political order, and for legitimizing programs of radical reconstruction, which may be understood as requiring violence. Michael Walzer (1965), for example, famously characterized Puritanism as the template for all forms of social revolution, while Shmuel Eisenstadt (2005) traced the origin of what he called totalistic or Jacobin forms of radical politics to the transposition of the transcendental religious visions generated by axial age civilizations from restricted and marginal spaces into the center of politics. More generally still, the charismatic or prophetic moment in religion - like charismatic authority in general - is intrinsically disruptive and even "revolutionary," as Weber argued. (And it is no accident that both Walzer and Eisenstadt were deeply influenced by Weber.)

\footnotetext{
${ }^{8}$ The recruitment of suicide attackers need not require a durable reorganization of self; a temporary reorganization of the self may suffice.

${ }^{9}$ The notion of "virtuoso" religiosity was central to Weber's sociology of religion: see for example 1978a:538-541.

${ }^{10}$ In addition, political otherhood can be intensified by being given a religious gloss: "Crusaders"; "Great Satan"; "axis of evil," etc.

${ }^{11}$ On the intensely contested category of takfir - a procedure by which one Muslim declares another (nominal) Muslim to be an unbeliever or infidel, and thereby (in certain circumstances) a legitimate target of violence - see Hafez 2011. On the Jewish legal category of rodef, referring to a Jew who endangers the life of other Jews, and may therefore legitimately be killed in certain circumstances - a category implicated in the murder of Prime Minister Rabin by Yigal Amir in 1995 see Appleby 2000:81-85 and Pedahzur and Perliger 2009: Chapter 5.
} 
Of course, religious understandings of transcendent reality can also be mobilized against challenges to the existing social and political order; they can be used to legitimize the violent repression of challenges and challengers.

The third mechanism is the mobilization of rewards, sanctions, justifications, obligations, and what might be called deep, ultimate, or constitutive meanings. This too is of course a generic social process. Yet religious entrepreneurs and organizations - or political entrepreneurs who speak the language of religion - may be able to mobilize an additional layer of rewards, sanctions, justifications, obligations, and ultimate meanings. This is suggested most clearly by the spectacular surge since 2000 in religiously legitimated or rationalized suicide attacks. As political scientists have noted, specifically religious rewards and justifications are neither necessary for the recruitment of suicide attackers (as shown by the antireligious Tamil Tigers' extensive use of the tactic), nor sufficient (as shown by the fact that suicide attacks are overwhelmingly concentrated in a small number of theaters of conflict).

Yet religious justifications can transform such attacks from religiously prohibited "suicide" into religiously sanctioned "martyrdom," rewarded in the afterlife, where the sins of the martyr, who has "die[d] for the sake of God," will be washed away. Martyrdom, to be sure, has become a secular category, and in some contexts (notably Israel, the occupied territories, and Lebanon), strong social support for suicide bombers has led to their celebration as secular heroes. But while suicide bombing in the Israeli-Palestinian conflict has been intensively studied, that conflict accounts for only $4 \%$ of post-2000 suicide attacks. In Iraq, Afghanistan, and Pakistan, where more than $80 \%$ of post-2000 attacks have occurred, specifically religious rewards for "martyrdom" would appear to count for more in recruitment, especially in Pakistan and post-2011 Iraq, where suicide bombing does not involve the struggle against foreign occupation that political scientists have emphasized (Moghadam 2008). ${ }^{12}$

Political scientists have tended to discount such religious rewards and justifications (Gill 2011; Berman and Laitin 2008; Pape 2005). For most political scientists, religion provides an ex post rationalization and justification of conduct that can be explained in non-religious terms. If our aim is to explain organizational strategies, there is much to be said for such skepticism. But if our aim is to understand individuals' willingness to volunteer for suicide missions, dismissal of religion is less persuasive. The rationality and intelligibility of suicide bombing for organizations are one thing; its rationality and intelligibility for individuals who volunteer to sacrifice themselves are quite another. The religious legitimations that may serve as ex post rationalizations and justifications for organizations may operate as ex ante motivations for individuals - or at least as ex ante forms of sense-making that give suicide missions a larger meaning and purpose. What is opportunistically employed, or even cynically manipulated, by organizations may be deeply and sincerely felt by individual recruits.

The fourth mechanism is the experience of profanation. If one takes the categories sacred and profane in a broad Durkheimian sense, then sacred objects are simply those that are set apart and that must be treated with special respect. And profanation is simply an experienced or claimed violation of the required respect. Such "profanation" in the broadest sense - in the form of perceived disrespect towards special objects, places, or activities - can generate a violent response in many contexts that are not "substantively" religious.

${ }^{12}$ According to the CPOST database at the University of Chicago, nearly 3,500 suicide attacks, accounting for more than 35,000 deaths, occurred between 2000 and 2013, compared with 147 between 1982 and 1999. Of the post-2000 attacks, the overwhelming majority have occurred in conflicts defined in significant part by politicized Islam (the only significant exception is Sri Lanka, which accounts for less than $2 \%$ of the attacks, and less than $2 \%$ of the deaths). Iraq accounts for $45 \%$ of the post-2000 attacks, Afghanistan 25\%, and Pakistan 12\%. See http://cpostdata.uchicago.edu/search_new.php. Of attacks with known perpetrators, the large majority between 2001 and 2007 were carried out by Salafi-Jihadist groups (Moghadam 2008: 70). Of those with unknown perpetrators, three quarters were carried out in Iraq, where, according to Moghadam (2008:64), "the vast majority of organizations conducting suicide bombings are known to be Salafi jihadist." Pape's (2005) analysis, discounting the role of religion in suicide bombing, was based on data collected before the spike of the mid-2000s. 
But I'm interested here in profanation in a narrower, more substantively religious sense. Violence can be provoked by deliberate attempts to desecrate the central symbols of another religion, such as Florida Pastor Terry Jones' burning of a Qur'an in March 2011. ${ }^{13}$ But a religious profanation can also be experienced without having been intended as such. This need not lead to violence: outrage at a perceived profanation may be channeled into peaceful protest or institutional politics. But it may take extra-institutional and violent forms, as in the threats to Salman Rushdie's life and the bombing of bookstores after the publication of The Satanic Verses, the riots in response to the cartoons published by a Danish newspaper in $2005,{ }^{14}$ and the Charlie Hebdo massacre of last year.

The fifth mechanism concerns the translocal expandability of violent religious conflict. As a powerful form of imagined community that cuts across state boundaries, religion can serve as a vector of conflict expansion. The most spectacular recent instance of this has involved the participation of substantial numbers of Muslim foreign fighters in Afghanistan, Bosnia, Iraq, and Syria. Five things are worth underscoring about this mobilization. ${ }^{15}$ The first is its global rather than merely regional nature. ${ }^{16}$ The second is the bottom-up mobilization of foreign fighters. This distinguishes their participation from state-led transborder interventions - though of course there is also massive state-led transborder intervention in Syria. The third is the salience of ideal rather than material interests. At least in the earlier stages of the Syrian conflict, most foreign fighters were not paid - at least not very much - and they could not and cannot expect opportunities for looting that have motivated other forms of transborder military adventurism. The fourth is the discursive framing of transborder fighting as an individual religious duty by certain influential clerics, invoking the classical distinction in Islamic jurisprudence between matters that are obligatory for each Muslim individually and those that are obligatory for the community of believers as a whole. This is of course the position of only a small minority of Muslim clerics, but it has been an important resource for legitimating the participation of those who are receptive to the pan-Islamist discourse that highlights the urgent existential threat faced by the global Muslim ummah. The last aspect of contemporary foreign fighter involvement is the willingness to fight rather than simply contribute financially at a safe distance. This distinguishes foreign fighters from ethnic diaspora financial support for distant nationalist movements and insurgencies, such as the Tamil Tigers, PKK, and IRA.

In short, the contemporary mobilization of foreign fighters draws on a deeply (though of course unevenly) felt sense of personal religious obligation to defend the global imagined community of the ummah against a vividly felt existential threat.

The sixth and final mechanism I want to discuss concerns the structure of religious fields. Decentralized and hyper-competitive religious fields can generate structural incentives for radicalization that can foster intransigent and sometimes violent religious and political action. This was true of the post-Reformation Wars of Religion in 16th and 17th century Europe. A similar dynamic is at work today in the fragmented and hyper-competitive field of contemporary Sunni Islam. The religious field of Sunni Islam has always been decentralized; but fragmentation and struggles over authority have intensified in the last half-century as mass education and new media have undermined the authority of the traditionally educated ulama (legal scholars) and created space for large numbers of new interpreters to claim the right to speak in the name of Islam (Eickelman and Piscatori 1996:131-132; Anderson 2003; Krämer and Schmidtke 2006; Krämer 2006).

\footnotetext{
${ }^{13}$ Jones succeeded in provoking a violent response in Afghanistan (though his more intensively publicized plans to burn large numbers of Qur'ans on the anniversary of the September 11 attacks in 2010 and 2013 remained unrealized).

${ }^{14}$ Occurring many months later, the latter were of course organized, not spontaneous. But the sense of injury and outrage over such profanation (Eickelman and Piscatori 1996: 16; Mahmood 2009) - nursed and cultivated by political entrepreneurs, to be sure, but not created by them - can serve as a potent if volatile political resource.

${ }^{15}$ My account here relies primarily on Hegghammer 2010.

${ }^{16}$ An estimated 20,000 foreign fighters were involved in Syria at the beginning of 2015, a fifth of them residents or citizens of Western European countries. (http://icsr.info/2015/01/foreign-fighter-total-syriairaq-now-exceeds-20000-surpassesafghanistan-conflict-1980s/ ).
} 
In the theoretical language of Pierre Bourdieu, perspective, fields generate incentives for different kinds of position-taking for those in different positions (Bourdieu and Wacquant 1992:94115; Bourdieu 1993). Those who possess little of the most consecrated forms of field-specific capital - in the field of Sunni Islam, this means those without the deep jurisprudential knowledge of the ulama - seek to valorize new forms of capital. They are structurally disposed toward heteronomy, that is, towards opening the religious field to forms of capital and principles of valuation derived from other fields. These include political or even military capital on the one hand, and the capital of notoriety, fame, or media exposure on the other. They are also structurally disposed toward strategies of outbidding, in which they claim to be more truly Islamic than others, and toward strategies of provocation, intended to gain visibility and recognition.

This mechanism is not a specifically religious one. New entrants to all fields, not just religious ones, are disposed toward heteronomy, outbidding, and provocation. Precisely because they lack consecrated forms of field-specific capital, they seek to valorize new forms of capital. But in the fragmented, hyper-competitive field of Sunni Islam, with no structures in place for the authoritative regulation or moderation of internal conflict and competition, these general structural tendencies are greatly accentuated. ${ }^{17}$

Structural incentives for heteronomy, provocation, and outbidding in the religious field can align with structural incentives for heteronomy in the political field. ${ }^{18}$ This is the case in parts of the Middle East today, where regimes have been defined by a twofold exclusion, at once religious (on the part of repressively secularist regimes) and ethnoreligious (on the part of substantively ethnocratic regimes). Throw into the mix what can be represented as the neo-imperial involvement of "Christian" powers, and you get strong incentives to "religionize" political competition and conflict. There are few and ineffective institutional arrangements to protect politics from religion, just as there are few and ineffective institutional arrangements to protect religion from politics, and specifically from entanglement in struggles for control over the means of violence. ${ }^{19}$

So let me conclude. None of the modalities and mechanisms I have discussed is unique to religion. Yet religion provides a distinctively rich and interlocking matrix of such modalities and mechanisms. Strong forms of religious exceptionalism are easily rejected; but the strongly generalizing counter-claim that there is nothing distinctive about religiously informed political conflict and violence is equally unsatisfactory. Religion can define reality, constitute communities, nurture

${ }^{17}$ Kalyvas (2000) and Casanova (2005) have underscored, in differing contexts, the paradoxical political significance of the contrast between the fragmentation of authority in Sunni Islam and the centralization of authority in Catholicism. Kalyvas (2000) analyzes the strategic dilemma facing illiberal or non-liberal religious political movements that are poised to win sweeping electoral mandates in emerging democracies. He compares a Catholic movement in late 19th century Belgium and an Islamist movement in late 20th century Algeria, each divided between moderates and radicals. In order to forestall a preemptive move by secular incumbents to exclude them by force from the political game, such movements must credibly commit to accepting the secular, liberal democratic order; they must credibly signal that they will not seek to implement their maximalist program. Moderate Catholics in the Belgian the movement were able to do this, with the decisive help of the Belgian Catholic Church, which - with support from the Pope - decisively intervened against radicals in the movement. The fragmented, decentralized religious field of Sunni Islam, however, prevented moderate Muslims in the Algerian movement from doing the same. Democratization, ironically, was "facilitated by a hierarchical and autocratic religious structure and hindered by a decentralized and democratic religious structure" (393). Casanova notes a similar paradox: the Catholic aggiornamento - the striking and rapid shift towards accepting liberalism, democracy, and modernity associated with Vatican II - was decisively facilitated by the hierarchical and centralized structure of the Church. The pluralization and democratization of the religious sphere in Sunni Islam, on the other hand, have at best ambiguous implications for political liberalism, pluralism, and democracy (100-101).

${ }^{18}$ This is consistent with the suggestion of Gorski and Türkmen-Dervişoğlu (2013:204) that religious nationalism involves the "synchronization of 'principles of vision and di-vision' across the religious and nonreligious fields, such that the religious and national principles became more salient and more closely aligned... [as a result of] strategic alliances between elite groupings across the relevant fields." For a field-theoretic analysis of religion and politics in Saudi Arabia, see Lacroix 2011.

${ }^{19}$ On the variable institutionalization of the "twin tolerations" that protect the autonomy of religion vis-à-vis politics and the autonomy of politics vis-à-vis religion, see Stepan 2001, chapter 11. 
powerful emotions, generate commitment, resocialize and reorganize the self, radically devalue the existing order, impose obligations, offer rewards and sanctions, furnish justifications, and intensify threats and dangers. It links cognitive definitions of ultimate reality with structures of feeling and obligation. In so doing it can authorize, legitimate, enable, and even require violent action in the face of urgent threats, profanations of sacred symbols, and extreme otherhood.

That religion can do so does not of course mean that it will do so. And the very same mechanisms that can enable religiously informed political conflict to turn violent can also enable powerful forms of nonviolent solidaristic or humanitarian social action (Stamatov 2013). The social production of hyper-committed selves can nurture moral heroism; the construction of urgent threats can radically delegitimize social evils such as exploitation, slavery, or even war itself; transnational religion can serve as a vector of expansion of humanitarian campaigns such as the anti-slavery movement in the nineteenth century; and fragmented and hypercompetitive religious fields may generate stances (such as that of the Quakers) that categorically reject violence.

There is, then, no intrinsic connection between religion and political violence. But religion does provide a potent assemblage of moral, ideological, and organizational resources that can, in certain contexts, inform, legitimate, or sustain violent conflict, just as they can inform, legitimate, or sustain the most admirable forms of moral and political engagement. The analytical challenge, for students of conflict and violence, is to specify the conditions and contexts in which particular religious practices, discourses, fields, organizations, and structures of sentiment can contribute to the production, reproduction, and transformation of political conflict and violence. Taking up that challenge is beyond the scope of this lecture. Doing so would require a different mode of analysis, at once historical, comparative, and contextual - in short, a Weberian mode of analysis - geared toward specifying when, where, how, and why the modalities, mechanisms, and dynamics outlined here are activated in ways that play into political conflict and violence.

My aim in this paper has been a more modest one: to contribute to the development of a more nuanced and qualified particularizing account of the distinctive ways in which religion can enter into political conflict and violence. Such a qualified particularizing account, I have suggested, should be understood as a complement to, not as a substitute for, a generalizing account. We should be attuned to the distinctively religious stakes of certain political conflicts, informed by distinctively religious understandings of right order that are expressed in claims for the substantive regulation of public life in accordance with religious principles; and we should also be sensitive to the distinctiveness of religion as a rich matrix of interlocking modalities and mechanisms that can - in certain contexts contribute to political conflict and violence even when the stakes of the conflict are not distinctively religious. Yet at the same time, we should recognize the ways in which many putatively religious conflicts - or conflicts in which the parties are identified in religious terms - are fundamentally similar in structure and dynamics to other conflicts over political power, economic resources, symbolic recognition, or cultural reproduction. 


\section{References}

Anderson, Jon W. 2003. "The Internet and Islam's New Interpreters." Pp. 45-60 in New media in the Muslim world: the emerging public sphere, Indiana series in Middle East studies, edited by Dale F. Eickelman and Jon W. Anderson. Bloomington, Ind: Indiana University Press.

Appleby, R. Scott. 2000. The Ambivalence of the Sacred: Religion, Violence, and Reconciliation. Lanham, MD: Rowman \& Littlefield Publishers.

Barth, Fredrik. 1969. "Introduction." Pp. 9-38 in Ethnic groups and boundaries: the social organization of culture difference, edited by Barth, Fredrik. Boston: Little, Brown and Company.

Berman, Eli, and David D. Laitin. 2008. "Religion, Terrorism and Public Goods: Testing the Club Model." Journal of Public Economics 92(10-11):1942-67.

Bourdieu, Pierre. 1993. "Some Properties of Fields." Pp. 72-77 in Sociology in Question. London: SAGE.

Bourdieu, Pierre, and Loi c J. D. Wacquant. 1992. An Invitation to Reflexive Sociology. Chicago: University of Chicago Press

Brubaker, Rogers. 2015a. Grounds for Difference. Cambridge, Mass.: Harvard University Press. 2015b. "Religious Dimensions of Political Conflict and Violence." Sociological Theory 33, no. 1: 1-19.

Brubaker, Rogers, and David D. Laitin. 1998. "Ethnic and Nationalist Violence." Annual Review of Sociology 24(1):423-52.

Casanova, Jose. 2005. "Catholic and Muslim Politics in Comparative Perspective." Taiwan Journal of Democracy 1(2):89-108.

Eickelman, Dale F., and James P. Piscatori. 1996. Muslim Politics. Princeton, N.J: Princeton University Press.

Eisenstadt, S. N. 2005. "Religious Origins of Modern Radicalism.” Theoria 52(106):51-80.

Friedland, Roger. 2002. "Money, Sex, and God: The Erotic Logic of Religious Nationalism." Sociological Theory 20(3):381-425.

Gill, Anthony. 2011. "Religion and Violence: An Economic Approach." Pp. 35-49 in The Blackwell Companion to Religion and Violence, edited by Andrew R. Murphy. Wiley-Blackwell.

Gorski, Philip S., and Gülay Türkmen-Dervişoğlu. 2013. "Religion, Nationalism, and Violence: An Integrated Approach." Annual Review of Sociology 39(1):193-210.

Hafez, Mohaddmed M. 2011. "Takfir and Violence against Muslims." Pp. 25-46 in Fault lines in global Jihad: organizational, strategic and ideological fissures / Fishman, Brian., Political violence; Variation: Cass series on political violence., edited by Assaf Moghadam and Fishman, Brian. Milton Park, Abingdon, Oxon ; New York: Routledge.

Hawley, John Stratton. 1994. Fundamentalism and Gender. Oxford University Press.

Hefner, Robert W. 2011. Shari' a Politics: Islamic Law and Society in the Modern World. Indiana University Press.

Hegghammer, Thomas. 2010. "The Rise of Muslim Foreign Fighters: Islam and the Globalization of Jihad." International Security 35(3):53-94.

Horowitz, Donald L. 1985. Ethnic Groups in Conflict. Berkeley: University of California Press.

Jasper, James M. 1997. The Art of Moral Protest: Culture, Biography, and Creativity in Social Movements. University of Chicago Press.

Juergensmeyer, Mark. 2000. Terror in the Mind of God: The Global Rise of Religious Violence. Berkeley: University of California Press.

Kalyvas, Stathis N. 2000. "Commitment Problems in Emerging Democracies: The Case of Religious Parties.” Comparative Politics 32(4):379-98.

Krämer, Gudrun, and Sabine Schmidtke. 2006. "Introduction: Religious Authority and Religious Authorities in Muslim Societies. A Critical Overview." Pp. 1-14 in Krämer and Schmidtke, eds., Speaking for Islam: Religious Authorities in Muslim Societies. Leiden and Boston: Brill. 
Krämer, Gudrun. 2006. "Drawing Boundaries: Yusuf al-Qaradawi on Apostasy." Pp. 181-217 in Krämer and Schmidtke, eds., Speaking for Islam: Religious Authorities in Muslim Societies. Leiden and Boston: Brill.

Lacroix, Stéphane. 2011. Awakening Islam: The Politics of Religious Dissent in Contemporary Saudi Arabia. Cambridge, Mass: Harvard University Press.

Mahmood, Saba. 2009. "Religious Reason and Secular Affect: An Incommensurable Divide?" Critical Inquiry 35(4):836-62.

Moghadam, Assaf. 2008. "Motives for Martyrdom: Al-Qaida, Salafi Jihad, and the Spread of Suicide Attacks." International Security 33(3):46-78.

Pape, Robert Anthony. 2005. Dying to Win: The Strategic Logic of Suicide Terrorism. Random House. New York: Random House.

Pedahzur, Ami and Arie Perliger. 2009. Jewish Terrorism in Israel. New York: Columbia University Press.

Rothschild, Joseph. 1981. Ethnopolitics, a Conceptual Framework. New York: Columbia University Press.

Snow, David A., and Richard Machalek. 1984. "The Sociology of Conversion." Annual review of sociology 167-90.

Stamatov, Peter. 2013. The Origins of Global Humanitarianism. New York: Cambridge University Press.

Stepan, Alfred C. 2001. "The World's Religious Systems and Democracy: Crafting the 'twin Tolerations." Pp. 213-53 in Arguing Comparative Politics. Oxford ; New York: Oxford University Press.

Walzer, Michael. 1965. The Revolution of the Saints; a Study in the Origins of Radical Politics. Cambridge: Harvard University Press.

Weber, Max. 1946. From Max Weber: Essays in Sociology. edited by Hans Heinrich Gerth and C. Wright Mills. New York: Oxford University Press.

Weber, Max. 1978a. Economy and Society: An Outline of Interpretive Sociology. Berkeley: University of California Press.

Weber, Max. 1978b. Max Weber: Selections in Translation. Cambridge ; New York: Cambridge University Press.

Wessinger, Catherine. 2000. Millennialism, Persecution, and Violence: Historical Cases. Syracuse University Press.

Wimmer, Andreas. 1997. "Who Owns the State? Understanding Ethnic Conflict in Post-Colonial Societies." Nations and Nationalism 3(4):631-66. . 2013. Ethnic Boundary Making: Institutions, Power, Networks. Oxford Studies in Culture and Politics. New York: Oxford University Press. 
